\title{
PERSPECTIVE
}

\section{Clinical and genetic patterns of neurofibromatosis 1 and 2}

\author{
Nicola K Ragge
}

\section{General introduction to the neurofibromatoses}

The diseases traditionally known as neurofibromatosis have now been formally separated into two types: neurofibromatosis type 1 or NF1 (the type described by von Recklinghausen) and neurofibromatosis type 2 or NF2 (a much rarer form). ${ }^{1}$ It is now recognised that although they have overlapping features, including an inherited propensity to neurofibromas and tumours of the central nervous system, they are indeed separate diseases and map to different chromosomes -17 for NF1 and 22 for NF2. Furthermore, developmental abnormalities such as hamartomas occur in both types of neurofibromatosis, illustrating a need to define the role of the normal NF genes in development.

There may also be further forms of neurofibromatosis, including NF3, NF4, multiple meningiomatosis, and spinal schwannomatosis, that do not fit precisely into current diagnostic classifications. These further forms may eventually map to different genes. For their clinical features, the reader is referred to a more detailed text. ${ }^{2}$ Segmental neurofibromatosis (NF5) is a localised form of neurofibromatosis affecting a region of the body. Here the café au lait patches, neurofibromas, and even Lisch nodules are all found ipsilateral to the tumours and not crossing the midline. Interestingly, individuals with segmental NF can have children with classic NF1. ${ }^{3}$ This implies either a common gene locus or possible gonadal mosaicism. There may be other partial forms of neurofibromatosis. For instance, in the case of NF1, some parents manifesting Lisch nodules alone may give rise to offspring with a fully expressed disorder. ${ }^{4}$ The explanation for this variable expressivity is still unclear.

\section{HISTORICAL ASPECTS}

Early descriptions of neurofibromatosis are surprisingly sparse, given its highly characteristic appearance. Possible portrayals exist in an Austrian monasteric manuscript from the thirteenth century, and in Monstrorum Historia, a posthumous work based on the observations of Aldrovandi, a sixteenth century naturalist, physician, and philosopher from Bologna, Italy, published in $1642 .^{5-10}$ However, it was not until the eighteenth century that the first compelling illustrated medical descriptions appeared by Tilesius ${ }^{11}$ and Akenside. ${ }^{12} 13$ Various works of art around this time also reproduced this condition including an illustrative plate by B de Bakker in Histoire Naturelle by Buffon in $1749^{914}$ and possibly an early seventeenth century carving of a book-seller. ${ }^{2}$ By the nineteenth century detailed medical articles on neurofibromatosis were published, including a treatise by Smith ${ }^{75}$ and pieces by Virchow ${ }^{16}$ and Hitchcock, ${ }^{17}$ which antedated von Recklinghausen's monograph published in $1882 .{ }^{18}$ Neurofibromatosis (now type 1 NF) came to be known as von Recklinghausen's disease following a classic description in which von Recklinghausen was the first to emphasise clinicopathological correlation and a common neural origin for the various tumour types.

\section{Neurofibromatosis type 1}

\section{CLINICAL ASPECTS}

Neurofibromatosis type 1 (NF1) is the commonest form of neurofibromatosis and has a frequency of about 1 in 3000 to 1 in $3500 . .^{19} 20$ Although the gene is almost $100 \%$ penetrant, the disease itself has extremely variable expressivity. ${ }^{20} \mathrm{About}$ $50 \%$ of index cases and $30 \%$ of all NF1 cases are considered to be new mutations. The high mutation rate may be due in part to the large size of the gene and its transcript, or possibly to the presence of sequences within the gene highly susceptible to mutation.

\section{Clinical features}

Particular clinical features are critical for establishing the diagnosis of NF1 in any individual, whereas a multitude of other features are commonly and variably present. The disease is defined using the clinical criteria outlined in Table 1. Typically, NF1 is associated with the formation of multiple tumour types in addition to the neurofibromas, including optic gliomas, neurofibrosarcomas, astrocytomas, meningiomas, ependymomas, and phaeochromocytomas. Individuals with NF1 may also be at increased risk of developing other malignancies seen more commonly in the general population - for example, chronic myelogenous leukaemia of childhood, Wilms' tumour, and rhabdomyosarcoma. ${ }^{2122}$ Many of the tissues involved in either dysplasia or neoplasia are derived from the neural crest.

Skin hyperpigmentation. Multiple café au lait patches (CAL) are present in over $99 \%$ of individuals with NF1, and can range in size from a few millimetres to more than $50 \mathrm{~cm}$ in diameter (Fig 1). ${ }^{23}$ They tend to be present at birth or develop within the first year of life. Larger areas of hyperpigmentation may be either a typical flat CAL or may outline an underlying plexiform neurofibroma. When the hyperpigmentation overlying a plexiform neurofibroma extends to the midline, it may signify underlying spinal cord involvement. Individuals with NF1 may also have a diffuse skin hyperpigmentation or innumerable freckles. Freckling may be congenital, when it is usually seen in the axillary region, or acquired later in childhood, when it develops in the inguinal and other intertriginous zones, at points of friction, or diffusely over the entire body. In a large proportion of white adults with NF1, biopsies of CALs demonstrate a high

\section{Table 1 Diagnostic criteria for neurofibromatosis 1}

The diagnostic criteria are met if a person has two or more of the following: Six or more café au lait macules over $5 \mathrm{~mm}$ in greatest diameter in prepubertal persons and over $15 \mathrm{~mm}$ in greatest diameter in postpubertal preps persons and over $15 \mathrm{~mm}$ in greatest diameter in postpubertal persons Freckling in the axillary or inguinal regions Optic glioma

Two or more Lisch nodules (iris hamartomas)

A distinctive osseous lesion such as sphenoid dysplasia or thinning of long bone cortex with or without pseudarthrosis

A first degree relative (parent, sibling, or offspring) with neurofibromatosis 1 by the above criteria 


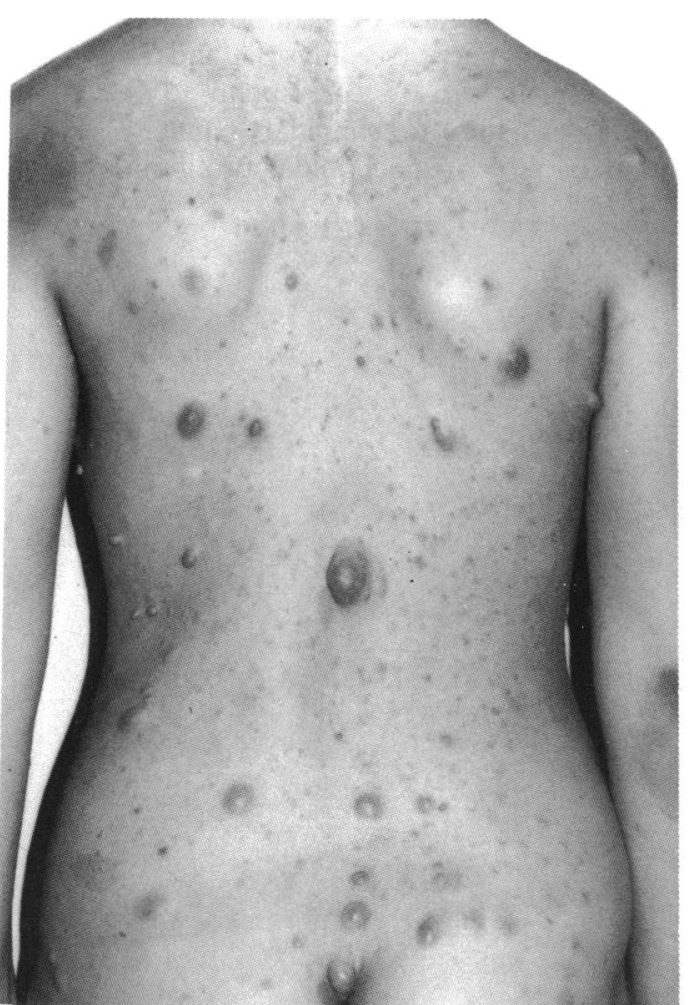

Figure 1 Multiple cutaneous neurofibromas and café au lait patches (for example, over upper left buttock) (courtesy of VM Riccardi).

density of cellular giant pigment markers called melanin macroglobules (or macromelanosomes). ${ }^{24}$

Neurofibromas. Neurofibromas can be broadly divided into four types, although more than one type may coexist in any lesion. ${ }^{23}$ The classic skin neurofibromas of NF1 are cutaneous (Fig 1). These discrete, soft, fleshy, often multiple tumours develop towards the end of the first decade just before puberty. They are initially sessile, but later often become pedunculated. Early onset of neurofibromas may signify more numerous lesions eventually. ${ }^{23}$ Pruritus of the skin overlying the neurofibromas occurs commonly, possibly due to an effect of tumour associated mast cells. Skin neurofibromas can appear spontaneously, or after trauma to the skin when they may be preceded by itching. Pregnancy can stimulate the growth and appearance of neurofibromas.

The other three types of neurofibromas - the subcutaneous, nodular plexiform and diffuse plexiform - represent a continuum. Subcutaneous neurofibromas are discrete, often painful tumours as they are distributed along the course of major and minor nerves. They may be associated with the nodular plexiform neurofibroma, which involves major nerve plexuses, dorsal nerve roots, or autonomic nerves overlying viscera or blood vessels. Severe neurological complications can result. The final type is the diffuse plexiform neurofibroma which encompasses all the other types and insinuates the tissue planes. These arise from the neural tissues and are a histological combination of neurons, fibroblasts, Schwann cells, blood vessel elements, mast cells, and occasionally pigment cells. ${ }^{20}$ Large plexiform neurofibromas in childhood may be associated with segmental hypertrophy.

Malignant transformation can occur in all types of neurofibromas, but is much more common in those with a deeper somatic location. The overall risk of neurofibrosarcoma to the NF1 patient is about $5 \% .{ }^{23} 25$ The cardinal signs of malignant transformation are pain, increasing tumour size, and focal neurological deficit. ${ }^{20}$ If a skin neurofibroma is being constantly traumatised by friction with clothing, it is generally recommended that it should be removed because of a potential risk of malignant transformation.



Figure 2 Iris hamartomas (Lisch nodules) in a patient with neurofibromatosis type 1 (arrows).

\section{Ocular manifestations}

Iris hamartomas. Iris hamartomas, also known as Lisch nodules, are melanocytic iris naevi, and occur in almost all adults with NF1 (Fig 2). If present with other diagnostic signs of NF1 (for instance, café au lait patches or neurofibromas), iris hamartomas confirm the diagnosis. However, their appearance in the absence of other signs is not diagnostic of NF1, merely highly suggestive. Rarely they may be the only sign of NF1, as described in one case of a parent with Lisch nodules and two affected sons with full NF1. ${ }^{26}$ Although the iris hamartomas are not easily detectable at birth, their prevalence increases to about $50 \%$ of 5 -year-olds, $75 \%$ of 15 year-olds, and $95-100 \%$ of adults over 25 years. ${ }^{27}$

Individuals with NF1 can display other ocular abnormalities. In the anterior segment these include prominent corneal, conjunctival, and ciliary nerves, ${ }^{28}$ congenital ectropion uveae, ${ }^{29}$ angle anomalies, posterior embryotoxon, buphthalmos, or later onset glaucoma ${ }^{30}$ especially in association with an ipsilateral plexiform neurofibroma of the eyelid, heterochromia iridis, iris mammillations ${ }^{28}$ neurofibromas of conjunctival and ciliary nerves, ${ }^{3031}$ and anterior subcapsular cataract. ${ }^{30}$ In the posterior segment they include hamartomas of the optic disc, ${ }^{32}$ retina, and choroid, ${ }^{28}$ combined pigment epithelial and retinal hamartomas (although this may be more a feature of NF2), ${ }^{33-35}$ which are sometimes associated with retinal tear and detachment, ${ }^{35}$ retinal haemangioma, ${ }^{35}$ choroidal 'ovoid bodies' of neurofibromatosis, ${ }^{293637}$ and anterior visual pathway gliomas (see below), including gliomas of the optic disc. Choroidal naevi and melanoma, ${ }^{38-40}$ congenital hypertrophy of the retinal pigment epithelium, myelinated nerve fibres, and sectoral retinitis pigmentosa have also been described in association with $\mathrm{NF} 1$, although, given their prevalence in the general population, their appearance may be coincidental. Ocular adnexae may be affected by plexiform neurofibromas of the eyelid and orbit, ${ }^{41}$ other orbital tumours, and absence of part of the sphenoid wing, with resultant pulsating exophthalmos.

\section{Optic pathway gliomas}

Gliomas of the anterior visual pathway are well recognised in NF1.2342-44 Although the frequency of this varies from $10-70 \%$ depending on the study, a retrospective analysis of reported cases ${ }^{45}$ and two recent prospective studies have shown the incidence of anterior pathway gliomas to be about $15 \%$ of NF1 patients. ${ }^{42}{ }^{46}$ However, in one study only $5 \%$ of NF1 patients were symptomatic from their gliomas, irrespective of location in the optic nerve or chiasm. ${ }^{42}$ Bilateral optic nerve gliomas or 'multicentric' gliomas made up between $30 \%$ and $80 \%$ of optic pathway gliomas, depending on 
whether minor optic nerve thickening was included in the data analysis. ${ }^{42}$ The recent use of magnetic resonance (MR) scanning demonstrates a higher incidence of subclinical lesions not detected on computed tomography (CT) scan, especially in the optic nerves. Only long term studies will demonstrate the significance of these lesions and their relation to the full spectrum of optic nerve gliomas.

Optic pathway gliomas can display features that are deemed to be diagnostic or highly suggestive of NF1. Bilateral optic nerve gliomas are felt to be pathognomonic of NF1.4344 Tubular expansion of one or both optic nerves, often with lengthening and kinking of the optic nerve (see Fig $3 \mathrm{~A}$ ), is highly characteristic of NF1 gliomas. The optic nerve glioma may sometimes extend to include the chiasm (see Fig 4). CT, and now MR scans demonstrate double density tubular thickening of fusiform optic nerve gliomas seen in NF1 (see Fig 3B). On T2 weighted MR images, a zone of

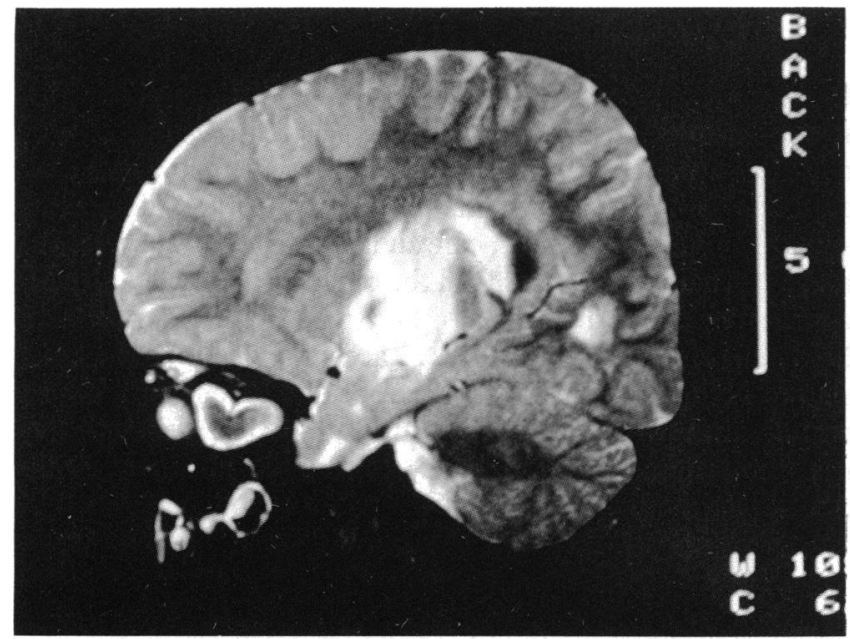

Figure 3A Parasagittal T2 weighted magnetic resonance scan with gadolinium showing enhancing optic glioma and intracerebral glioma in a patient with NFI.

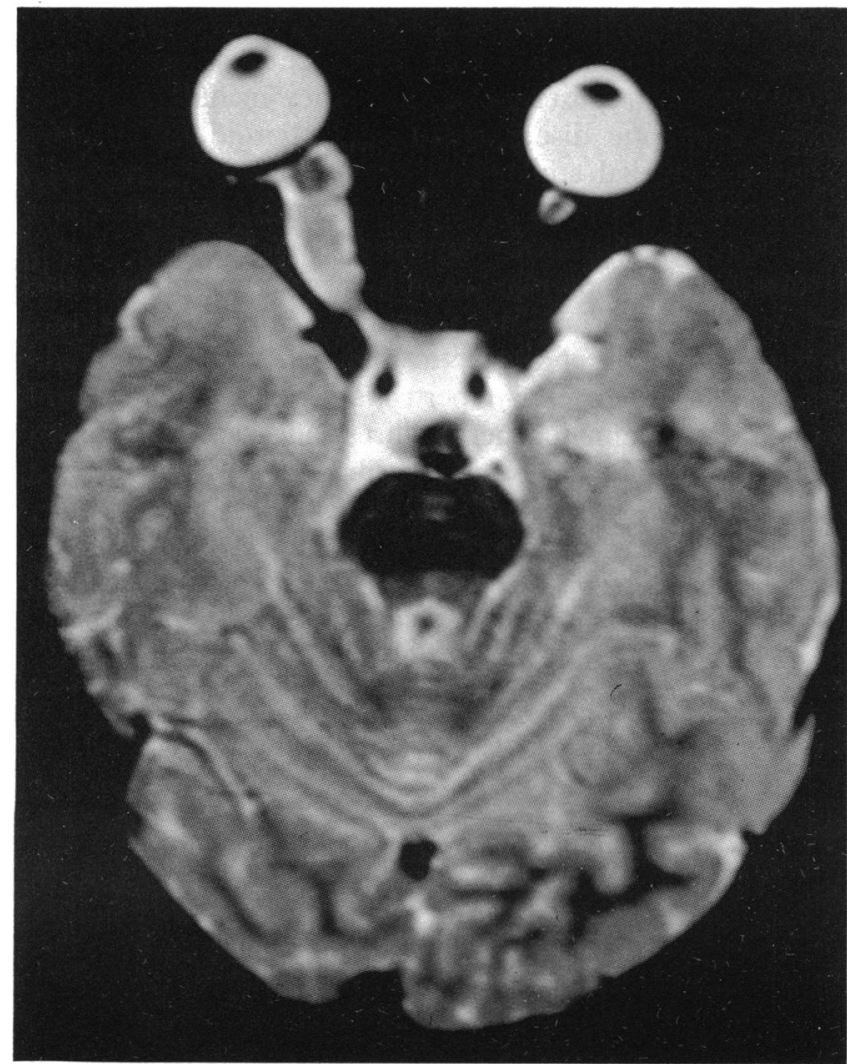

Figure 3B Coronal T2 weighted magnetic resonance scan with gadolinium showing left optic glioma in same patient as $(A)$ (courtesy of W F Hoyt). high intensity surrounds a central low density core, representing the optic nerve (see Figs $3 \mathrm{~A}$ and $3 \mathrm{~B}$ ). ${ }^{4344}$ The high intensity area appears to correspond to the pathological finding of perineural arachnoidal gliomatosis. ${ }^{434478}$ This perineural pattern of arachnoidal proliferation, compared

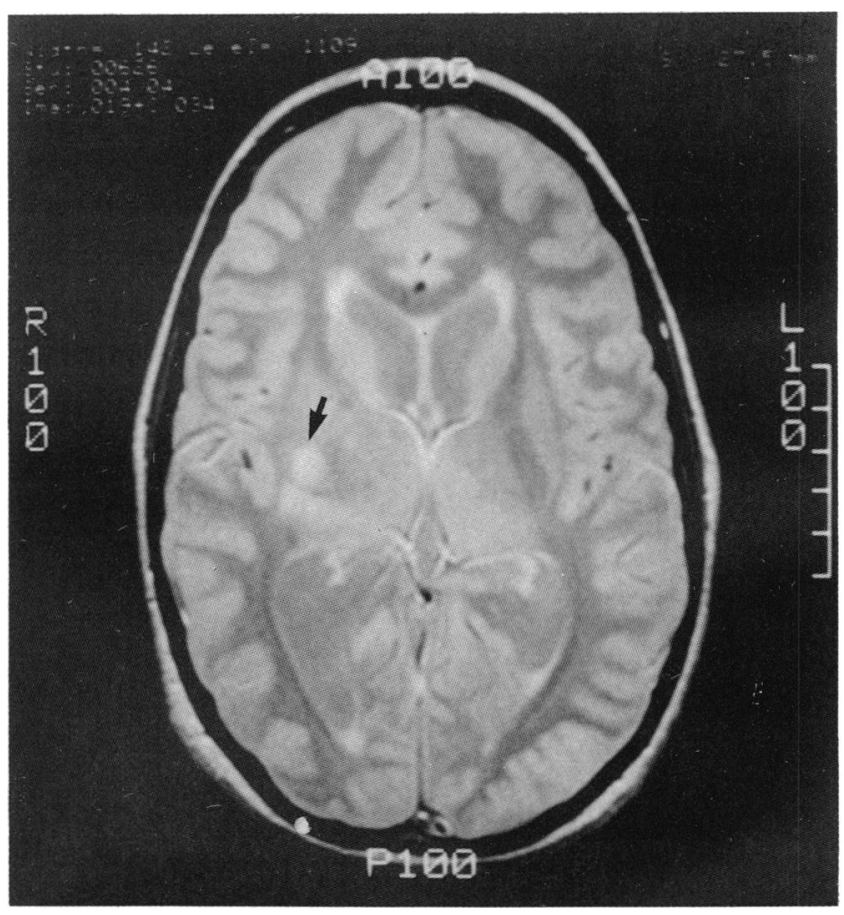

Figure 3C Coronal T2 weighted magnetic resonance scan of brain showing multiple 'bright spots' especially in the region of the basal ganglia and internal capsule (arrow) in patient with NFI (courtesy of W F Hoyt).

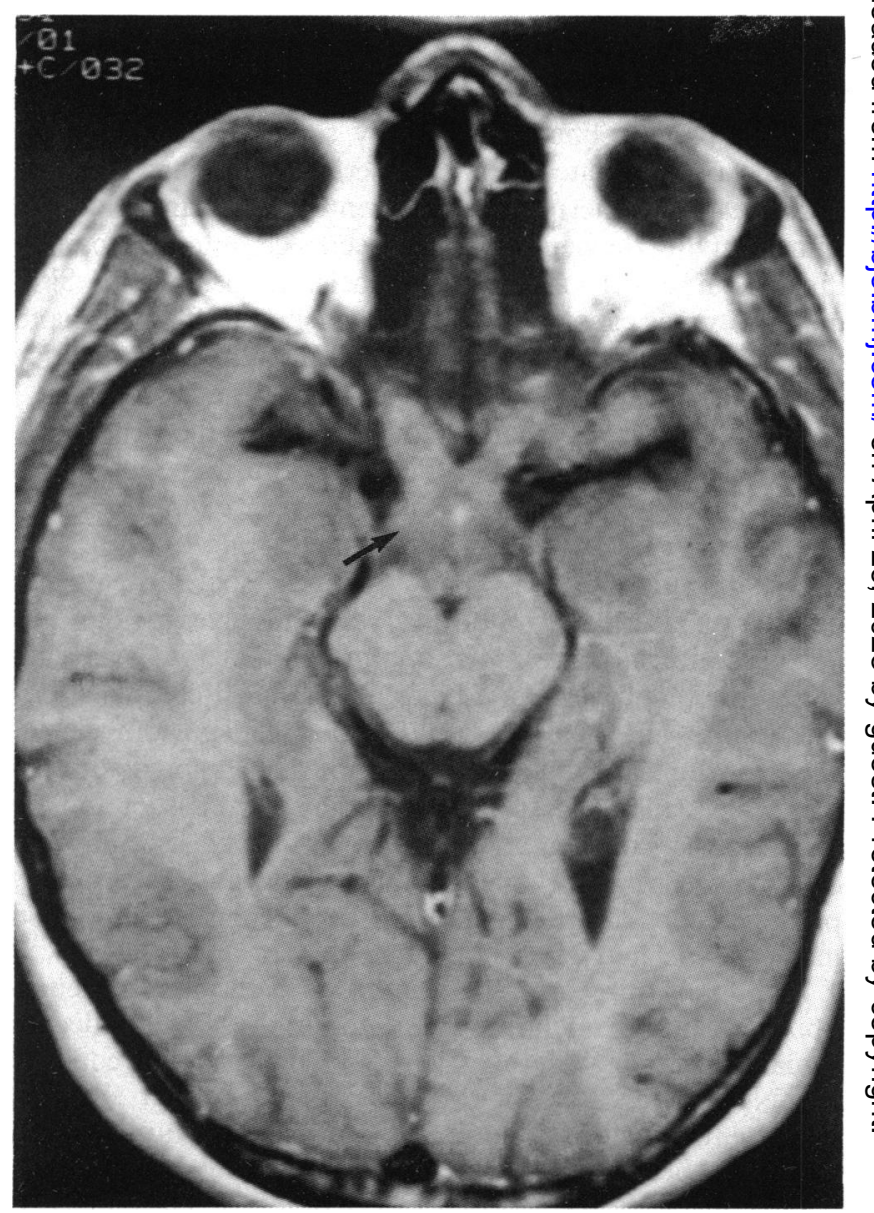

Figure 4 Tl weighted magnetic resonance scan showing a chiasmal glioma (arrow) in a patient with NF1 (courtesy of WF Hoyt). 
with the intraneural astrocytic proliferation seen more in isolated orbital optic gliomas, is thought by some, ${ }^{44}$ but not others, ${ }^{49}$ to be a characteristic feature of NF1 optic gliomas. A further distinctive feature in NF1 is the occurrence of a chiasmal glioma extending into both optic tracts, associated with bright foci in the brain parenchyma on T2 weighted images. These 'bright spots' are much more prevalent in children. Typically located in the basal ganglia and internal capsule, they are also seen in the midbrain, pons, cerebellar peduncles, and subcortical white matter (Fig 3C).

Controversy rages over whether the optic gliomas represent hamartomas or truly invasive astrocytomas. Analysis of the biological behaviour of optic gliomas in NF1 and non$\mathrm{NF} 1$ patients is confounded by many factors. ${ }^{50}$ Invasiveness and prognosis are related to position of the tumour and histological grade. In general, the more anterior gliomas that is, those located in the optic nerves alone, tend to have a more benign histology and are less invasive. ${ }^{47}$ This type tends to predominate in NF1. Many authors claim that optic pathway gliomas in NF1 patients are relatively benign, with the exception of large hypothalamic tumours, and that patients are more likely to succumb to second tumours. ${ }^{43451}$ Others believe them to have more invasive characteristics. ${ }^{52}$

\section{Other tumour types associated with NFI}

The frequency of other NFl tumour types has been discussed in other publications. ${ }^{2122}$ The spinal cord tumours include intramedullary astrocytomas, plexiform spinal or paraspinal neurofibromas that can extend over several segments, and isolated neurofibromas that may involve the neural foramina and spinal canal - 'dumbbell tumour'. Dural ectasia may cause enlargement of the neural coverings and lead to scalloping of the vertebra.

\section{Non-tumour manifestations of NFI}

Other clinical features of NF1 include kyphoscoliosis, which usually appears between the ages of 5 and 15 years and in only some cases is related to the presence of paravertebral neurofibromas; macrocephaly; mental retardation; learning disabilities; speech impediments; seizures; headaches; abdominal pain (intestinal neurofibromas, idiopathic); skin itching; early or delayed puberty; genu varum or valgum; tibial pseudarthrosis; hypertension (due to phaeochromocytoma, renal artery abnormalities); and pectus excavatum. ${ }^{2}$ The reader is also referred to more detailed descriptions in the book by Riccardi. ${ }^{2}$ Some patients with NFl have a phenotype overlapping with Noonan syndrome and these are more likely to display a microdeletion of chromosome 17 that incorporates the NF1 locus. ${ }^{2}$ Watson syndrome, a disease characterised by café au lait patches, mental retardation, and pulmonary stenosis, is thought to be allelic to NF1. ${ }^{53}$

\section{Screening and management of NFI}

For discussions of these aspects the reader is referred to several excellent discussions such as those by Riccardi ${ }^{23}$ and Pulst $^{54}$.

\section{GENETIC ASPECTS}

\section{The NF1 gene}

The gene for NF1 is located in the pericentromeric region of the long arm of chromosome 17: band q11.2. Two translocations - between chromosomes 1 and 17 and 17 and 22 involving the NF1 region provided the initial breakthrough for the location of the gene. ${ }^{55-58}$ Further work on these translocations and the technique of 'reverse genetics' led to the cloning and complete isolation of the NF1 gene. ${ }^{59-61}$ In 1991, the complete sequence of the NF1 gene product, called 'neurofibromin', was published ${ }^{62}$ and its cellular expression and function further characterised. . $3-65^{-15}$

The NF1 gene is one of the largest genes to code for a disease in humans, spanning $300 \mathrm{~kb}$ of genomic DNA (see Fig 5). The NF1 promoter region consists of a $\mathrm{CpG}$ rich region characteristic of housekeeping genes. The NF1 gene contains 49 exons (coding portions) which, after transcription, form a messenger RNA of $13 \mathrm{~kb}$. The 8454 nucleotides in this open reading frame give rise to neurofibromin, a protein product of 2818 amino acids. ${ }^{66}$ From its amino acid makeup, neurofibromin appears to be a cytoplasmic protein. Although the NF1 gene is expressed ubiquitously, it may have specialised functions within the neural crest cells. It has also been found to colocalise with microtubules and is presumably related to the cytoskeleton. ${ }^{6}$

Rather curiously, three small genes (OMgp, EV12A, EV12B) which read in the opposite direction from the rest of the larger NF1 gene, were found to be located within one intron (a 'non-coding region') of the NF1 gene. These small genes 'within a gene' are interesting: the OMgp (oligodendrocyte myelin glycoprotein) gene because of its role in cellcell communication in the central nervous system ${ }^{66}$ and the EV12A and EV12B genes because of their mouse homologues playing a role in murine leukaemias. These intron embedded genes are expressed, but their function is unknown. It is conceivable that they could merely be remnants of phylogenetically older genes ${ }^{67}$ However, there is no evidence that any mutations involving these embedded genes cause any special phenotype of NF1.

The 'GAP' in the NF1 gene. A major active portion of the NFl protein is thought to be the GAP (GTPase activating protein) region, so-called because of its striking sequence homology with the catalytic domain of mammalian GAP, and yeast equivalent proteins IRA 1 and 2.6869 This GAP region codes for a GAP-like protein which may act as a 'growth regulator', interacting with the ras oncogene (see below).$^{70}$ GAP itself is thought to be an important cell cycle regulatory protein $^{71}$ and interacts with the cellular oncogene ras, catalysing the conversion of the active GTP-bound form of ras to its inactive GDP-bound form. However, if the ras gene is mutated, the ras protein appears to lose its ability to bind to GAP and may continue to activate the cell, thus losing an important control mechanism. Whether ras controls GAP or vice versa is still undetermined. ${ }^{72}$

\section{Germline mutations in the NF1 gene}

Once a disease gene is cloned, the next step is to determine the types and consistency of mutations that give rise to the disease and if there is any phenotypic genotypic correlation. Several types of germline mutations in the NF1 gene have been characterised so far in individuals with NF1. These include megadeletions, which may lead to NF1 associated with other characteristics - for example, mental retardation or Noonan phenotype, ${ }^{273}$ microdeletions, point mutations, insertions, or translocations..$^{5907476}$ Although occasional coincident mutations within the NF1 gene in different families have been detected, ${ }^{59} 77$ this is not a typical feature of NF1 mutations. Lack of mutational hot spots is often a feature of tumour suppressor genes. Interestingly, the majority of new germline mutations arise on the paternal chromosome, ${ }^{78}$ possibly reflecting errors occurring during spermatogenesis. The effect of increasing paternal age on the frequency of new mutations is controversial.

\section{Mechanism of tumour formation in NFI}

The growth and differentiation of cells in the body are 




Figure 5 Schematic representation of NFI gene showing its position in the 11.2 region of the long arm of chromosome 17. When expanded (second level), the layout of genomic DNA can be seen with the $5^{\prime}$ end to the left and $3^{\prime}$ end to the right. The genomic DNA is transcribed to RNA in the direction left to right. The $5^{\prime}$ end of the gene contains factors upstream of the NFI gene itself which regulate the transcription of the gene, namely the tissue specific factors and the promoter region. The exons, which are coding regions of the gene eventually spliced to be contiguous, are separated by introns in the genomic DNA. The GAP. region is shown with cross hatching. There are three embedded minigenes $O M g p, E V 12 A$, and $E V 12 B$ which are transcribed in the opposite direction to the rest of the gene. After transcription to the messenger RNA precursor, which is shown in the third level, the exons are spliced to become contiguous in the mature RNA. The mature RNA is translated to form the protein neurofibromin.

controlled by two types of genes - equivalent to a car's accelerator and brake pedals. Those genes that facilitate these processes are called proto-oncogenes, or oncogenes; their complementary genes, which inhibit this process, are tumour suppressor (or growth suppressor) genes. A number of cellular oncogenes are known: these include ras, myc, src, fos, and erb, which have the capability of becoming permanently activated and facilitating uncontrolled cell proliferation. In a rather simple model, tumours can therefore arise by a combination of two processes: inactivating mutations of tumour suppressor genes (as seen in retinoblastoma ${ }^{79}$ ) or by activating mutations of cellular oncogenes. There is now increasing evidence that the NF1 gene acts as a tumour suppressor gene, when one would observe a second mutation or deletion in the other 'normal' copy of the NF1 gene in tumours as well as the inherited mutation in the NF1 gene. If it acted as a cellular oncogene, no such mutation would be seen (see below). In the former instance, the development of tumours would be a 'recessive' phenomenon, in the latter, a 'dominant' effect of the inherited gene.

The retinoblastoma paradigm is an attractive model for a mechanism for tumorigenesis in its simplest form. A germline mutation in the retinoblastoma $(\mathrm{Rb})$ gene followed by a somatic mutation in the retinal cell at the retinoblastoma locus or two separate somatic mutations in the two alleles of the $\mathrm{Rb}$ gene in the same retinal cell are required for a tumour to develop..$^{80} \mathrm{By}$ comparing the constitutional DNA with the tumour DNA from the same individual, a loss of allele can be detected. This is achieved because of the existence of DNA polymorphisms in the genetic makeup of all individuals. These polymorphisms produce different patterns in the maternal and paternal derived copies of any chromosome after restriction enzyme digest, separation by gel electrophoresis, and Southern blot analysis. ${ }^{81}$ Loss of one of these patterns can be detected in the tumour by comparison with the pattern of the constitutional DNA in the white cells. This is termed 'loss of heterozygosity'. For more precise definition of small genetic mutations or rearrangements, DNA sequencing can be performed. ${ }^{82}$

If tumours in NF1 behave in a similar fashion to retinoblastoma, a loss of all or part of the normal chromosome 17 allele corresponding to the NF1 gene would be seen in tumour DNA when compared with constitutional DNA from blood. Benign tumours from NFl patients have been analysed for loss of heterozygosity of the NFl gene. No gross deletions of chromosome 17 were found in neurofibromas, optic gliomas, plexiform neurofibromas, or brainstem neurofibromas. ${ }^{83}$ However, at least in neurofibromas, this result could have been confounded by contamination of tumour with normal tissue and lack of clonality of tumours, although this issue is controversial. ${ }^{85}$

In malignant tumours from NF1 patients, five out of 22 neurofibrosarcomas analysed showed loss of $17 p$ (short arm of chromosome 17) where the p53 gene is located (see below) and six showed loss of both $17 \mathrm{p}$ and $17 \mathrm{q}$ (long arm of chromosome 17) markers, including the NF1 region. 83848687 In other words, a total of $50 \%$ of neurofibrosarcomas showed loss of $17 \mathrm{p}$, which includes the $\mathrm{p} 53$ gene, suggesting that the p53 gene might be critical in the development of these tumours. However, recent observations suggest that both copies of the NF1 gene may be disrupted in neurofibrosarcomas. ${ }^{88}$ This has also been seen in phaeochromocytomas ${ }^{89}$ 
and in one malignant schwannoma. ${ }^{83}$ In two malignant astrocytomas, one (grade III) showed loss of both $17 p$ and $q$ and the other loss of $17 \mathrm{q}$ markers, ${ }^{83}$ one low grade astrocytoma showed no loss and a glioblastoma multiforme showed loss of $17 \mathrm{p}$ in multiple copies of chromosome $17 .^{87}$ The double deletion of the NF1 locus in certain tumours provides preliminary evidence that the NFl gene may behave as a tumour suppressor gene.

\section{Another important cell cycle regulator: the $p 53$ gene}

As mentioned earlier, the p53 gene may be important in tumour development in NF1. This gene is located on the same chromosome as the NF1 gene, but instead on the short arm. The $\mathrm{p} 53$ protein is a negative cell cycle regulator acting at the $G_{1}$ phase of replication, possibly at the level of transcription or the initiation of replication of genes important in the cell cycle regulation. ${ }^{90}$ The inherited tumorigenic conditions - the Li-Fraumeni syndrome and some familial cases of sarcoma - are associated with germline mutations in the p53 gene. ${ }^{90-94}$ However, even more important than the germline mutations are the acquired mutations in the p53 gene, the most frequent genetic change detected in spontaneous human cancers. Alterations of p53 either by mutation of the gene or subsequent inactivation of the protein have been strongly implicated in many different types of human cancer including colon and lung cancer, brain neoplasms, breast tumours, osteosarcoma, chronic myelogenous leukaemia, and many others. ${ }^{9095}$ Furthermore, at least in brain tumours, p53 mutations may offer a selective growth advantage to low grade tumour cells, allowing clonal expansion and progression to more malignant types of tumours. ${ }^{9}$ This finding is of special relevance in NFl tumours where p53 mutations have been demonstrated. ${ }^{87}$ Clearly tumour formation in NF1 involves a stepwise progression of acquired mutations within the NF1 and other oncogenes or tumour suppressor genes.

\section{NF1 gene mutations in other tumours}

Tumour suppressor genes can also show mutations in other 'uncharacteristic' tumour types. For example, retinoblastoma gene mutations are also seen in lung cancer and glioblastoma. ${ }^{9798}$ This may imply that an accumulation of mutations in growth suppressor genes and cellular oncogenes contributes to tumour progression. Likewise it has been shown that the NF1 gene has mutations in tumour types not usually associated with NF1: colon carcinoma, neuroblastoma, myelodysplastic syndrome, ${ }^{99}$ and malignant melanoma. ${ }^{100}$

\section{Possible functions of neurofibromin}

The characteristics of neurofibromin, the NFl gene product, are still being defined. There is a high likelihood that the wild type neurofibromin may have several different roles depending on the cell type and the physiological or developmental state of the cell. ${ }^{65}$ It could act via the ras protein in two different ways: by inhibiting ras activity and thereby suppressing mitogenesis and acting as a tumour suppressor protein, or by promoting the activity of ras - for example, in the differentiation of immature cells during embryogenesis. Furthermore, neurofibromin could act independently of ras, and, related to its association with intracellular microtubules, may play a part in cell division. ${ }^{6566}$

Other genetic influences in NFI

The variability in expression of disease phenotype in different members of the family who clearly have the same type of
NF1 gene mutation suggests that other genetic influences are at play. Miller and $\mathrm{Hall}^{101}$ suggested that the disease was more severe when the mutation was maternally derived. However, further studies failed to confirm this. ${ }^{102} 103$ Certain specific disease manifestations of NF1 may be affected by imprinting. These may include the association of juvenile chronic myelogenous leukaemia in NF1 with bone marrow monosomy 7, maternal inheritance, and predilection for boys. ${ }^{104}$ Otherwise the sex of the individual patient does not appear to influence the expression of disease with the exception of pregnancy effects. Some tumours including neurofibromas and, in NF2, vestibular schwannomas appear to grow under the effects of pregnancy hormones, and pregnancy can sometimes be the first time the disease is expressed.

\section{Prenatal testing}

Prenatal diagnosis or the assessment of carrier status is carried out in two ways. In some cases, for instance with haemoglobinopathies where a single DNA mutation occurs, the DNA can be directly analysed for the mutation. If the gene has not been cloned, or the mutations have not been identified, linkage analysis is performed. This method uses genetic markers flanking the gene itself to determine if a child has inherited the affected gene. It requires the DNA from three affected first degree relatives, in the case of a dominant condition like NF1 or NF2, usually an affected sibling and both parents. It relies on correct clinical diagnosis, accurate paternity status, informative markers, and close proximity and, therefore, a low recombination rate between marker and gene. $^{54}$

Although the gene for NF1 has been cloned, there are too many potential mutation sites to consider direct genetic analysis for mutations a feasible option at the present time. This means screening for sporadic cases of NF1 in the population is not possible. For inherited cases, however, the availability of intragenic polymorphic probes for the NF1 gene makes linkage analysis an accurate alternative for both prenatal testing and carrier assessment. ${ }^{105} 106$ However, in the case of prenatal testing, even when the fetus is diagnosed as carrying the mutant NF1 gene, the unpredictability of disease severity even with the same NF1 gene mutation makes genetic counselling exceedingly difficult. ${ }^{54}$

\section{SUMMARY}

Neurofibromatosis type 1 (NF1) is a dominantly inherited condition associated with the formation of multiple tumour types, including neurofibromas, optic gliomas, neurofibrosarcomas, astrocytomas, and phaeochromocytomas. The NF1 gene is located on the long arm of chromosome 17 and has recently been cloned and characterised. It contains an area coding for a GAP-like protein which may act as a 'growth regulator', interacting with the ras oncogene. Tumour formation in NF1 is a multistep process involving other growth regulator genes in addition to the NFl gene.

\section{Neurofibromatosis type 2}

\section{CLINICAL ASPECTS}

Although the first case description probably appeared as early as $1822,{ }^{107}$ neurofibromatosis type 2 (NF2), formerly known as central neurofibromatosis, has been defined as an entity distinct from neurofibromatosis type 1 only in the last decade or so. Clinical ${ }^{108}{ }^{109}$ and genetic evidence ${ }^{110}$ have now confirmed this. Since this division, a clearer, but also continuously evolving, clinical picture of NF2 is emerging. NF2 is a much rarer disease than NF1, with a population incidence of 1 in $33000-40000 .{ }^{111}$ About $50 \%$ of all cases ${ }^{111}$ 
Table 2 Diagnostic criteria for neurofibromatosis $2^{1}$

The diagnostic criteria are met if a person has either of the following:
(1) Bilateral eighth nerve masses seen with appropriate imaging techniques (for
example, computed tomographic or magnetic resonance imaging)
or
(2) A first degree relative with neurofibromatosis 2 and either unilateral eighth
nerve mass or two of the following:
- neurofibroma
meningioma
glioma
- swannoma
- juvenile posterior subcapsular lenticular opacity

Table 3 Comparison of clinical features of NF1 and NF2

\begin{tabular}{|c|c|c|}
\hline & $N F 1$ & $N F 2$ \\
\hline \multicolumn{3}{|l|}{ Skin: } \\
\hline Café au lait patches & ++ & + \\
\hline Subcutaneous, cutaneous, or plexiform neurofibromas & ++ & $+t$ \\
\hline Schwannomas ${ }^{\star}$ & - & + \\
\hline \multicolumn{3}{|l|}{ Spine: } \\
\hline Spinal neurofibromas & + & $(+)$ \\
\hline Spinal schwannomas & $?$ & ++ \\
\hline Meningiomas . & + & ++ \\
\hline Gliomas & + & ++ \\
\hline \multirow{2}{*}{\multicolumn{3}{|c|}{$\begin{array}{l}\text { Epenaymomas } \\
\text { Eye: }\end{array}$}} \\
\hline & & \\
\hline Optic glioma & ++ & ? \\
\hline Optic nerve sheath meningioma & - & + \\
\hline Lisch nodules & ++ & $(+)$ \\
\hline Cataracts & - & ++ \\
\hline Retinal hamartomas & + & + \\
\hline Myelinated nerve fibres & $(+)$ & ? \\
\hline Choroidal hamartoma & + & ? \\
\hline Choroidal naevus & + & ? \\
\hline Uveal melanoma & $(+)$ & $(+)$ \\
\hline Choroidal haemangioma & + & ? \\
\hline Preretinal fibrosis & - & + \\
\hline Combined pigment epithelial and retinal hamartoma & $(+)$ & + \\
\hline
\end{tabular}

$++=$ Profuse or common; $+=$ Present; $(+)=$ Rare; ?=Unknown

$\star$ Cutaneous or subcutaneous. $\dagger$ Special locations - palmar, nasolabial fold.

and $75 \%$ of index cases appear to represent new mutations (V M Riccardi, personal communication). The mutation rate is estimated to be $6.5 \times 10^{-6}$, lower than NF1."' Like NF1, the disease has an extremely high penetrance rate, over $95 \%$ in one study. ${ }^{108}$

The hallmark feature of NF2 is the presence of bilateral vestibular schwannomas ('acoustic neuromas'). However, according to NIH criteria, ${ }^{1}$ the diagnosis can also be made if there is a first degree relative with NF2 and there is either a unilateral eighth nerve mass, or any two of the following: neurofibroma, meningioma, glioma, schwannoma, or juvenile posterior subcapsular (or capsular) lens opacity (see Table 2). The main features that distinguish NF2 from NF1 are the presence of bilateral vestibular schwannomas, which have not yet been described in NF1, cutaneous schwannomas, spinal schwannomas, lack of Lisch nodules (with a few exceptions), fewer CALs, and the presence of juvenile onset cataracts. The comparative features are outlined in Table 3. Patients with NF2 tend to develop tumours of the neural coverings or linings, such as meningiomas, optic nerve sheath meningiomas, schwannomas, and ependymomas, whereas those with NF1 tend to develop neural or astrocytic tumours (astrocytomas, gliomas, and optic nerve gliomas). The reason for this is obscure at present.

\section{Clinical features}

As in NF1, there is huge variability in expression of the disease phenotype between individuals with NF2, both in terms of tumour type and location and the clinical severity of disease. ${ }^{112}$ However, in contrast to NF1, much of this variability is interfamilial rather than intrafamilial, suggesting that particular mutations within the NF2 gene may be important in determining severity. It has been suggested that within the clinical spectrum of NF2, there may be certain disease phenotypes that breed true within families. ${ }^{11111114}$ The types are:
(1) Wishart phenotype, ${ }^{107}$ characterised by early onset, rapid progression of hearing loss, and multiple associated tumours;

(2) Feiling-Gardner phenotype, which has a late onset of disease, slow progression of hearing loss, and few associated tumours ${ }^{115}{ }^{116}$

(3) Lee-Abbott phenotype, which is rarer and has a more variable age of onset and clinical progression of hearing loss, multiple associated spinal cord tumours, cerebellopontine angle meningiomas, and meningiomatosis en plaque of the falx. ${ }^{117}$

Although these phenotypes may eventually be confirmed by specific sites of genetic mutation within the NF2 gene, modern imaging techniques and genetic testing suggest a far greater variability in disease expression and many individuals cannot be classified readily into a particular group. ${ }^{111} 118$

Individuals with NF2 most commonly present with hearing loss, sometimes with concomitant tinnitus or unsteadiness. The average age of onset of hearing loss in NF2 is in the teens or twenties; however it is possible to present as early as the first or as late as the seventh decade. ${ }^{119}$ In one study, the presenting symptoms were most commonly bilateral hearing loss (50\% of individuals), then unilateral hearing loss $(21 \%)$, followed by imbalance or vestibular disturbance $(10 \%)$ and tinnitus (9\%). ${ }^{108}$ Headache, visual symptoms, facial paresis or other neurological symptoms accounted for about $10 \%$ of initial presentations. This pattern of presentation may change with increased awareness of the disease by the medical profession.

Schwann cell tumours of the central nervous system are the commonest type of tumour and include vestibular schwannomas (a more accurate term than acoustic neuroma), cranial nerve and spinal root schwannomas, and intramedullary schwannomas. Other tumours including multiple meningiomas, optic nerve sheath meningiomas, and gliomas are also common in NF2. Although the latter are of low histological grade, they can cause devastating disease if located in the brain stem or spinal cord. Deep plexiform neurofibromas demonstrate behaviour similar to those of $\mathrm{NF}$, leading to neurological dysfunction and possible malignant degeneration.

Dermatological signs of NF2 tend to be less profuse and are less often a presenting feature than in NF1. The skin signs, which overlap with NF1, include typical café au lait patches, which tend to be few in number, atypical areas of hyperpigmentation with indistinct borders, hypopigmented macules, hairy naevus, cutaneous neurofibromas, usually fewer than in NF1, and deep plexiform neurofibromas. However, more specific signs of NF2 include cutaneous schwannomas, which are harder than the more fleshy neurofibromas and have a rougher surface, subcutaneous schwannomas, which may be located in the spinal region (Fig 6), and neurofibromas in special locations - for example, nasolabial fold, palmar (V M Riccardi, personal communication).

\section{Ocular manifestations}

Recent observations suggest an extremely high prevalence of ocular findings in NF2. More than $75 \%$ of patients with NF2 are known to have premature loss of vision due to posterior subcapsular lens opacities. ${ }^{20} 121$ These opacities are rarely congenital, but are more often acquired in childhood or early adult life. Although posterior capsular or subcapsular cataracts were the first type to be described, it is clear that juvenile onset cortical cataracts can also be associated (Fig 7). ${ }^{121} 122$ Optic nerve sheath meningiomas are also a well described association with NF2 and can lead to progressive visual loss (Fig 8). ${ }^{122} 123$

Recently, isolated ${ }^{10}{ }^{125-127}$ and familial ${ }^{128}$ cases of combined

.




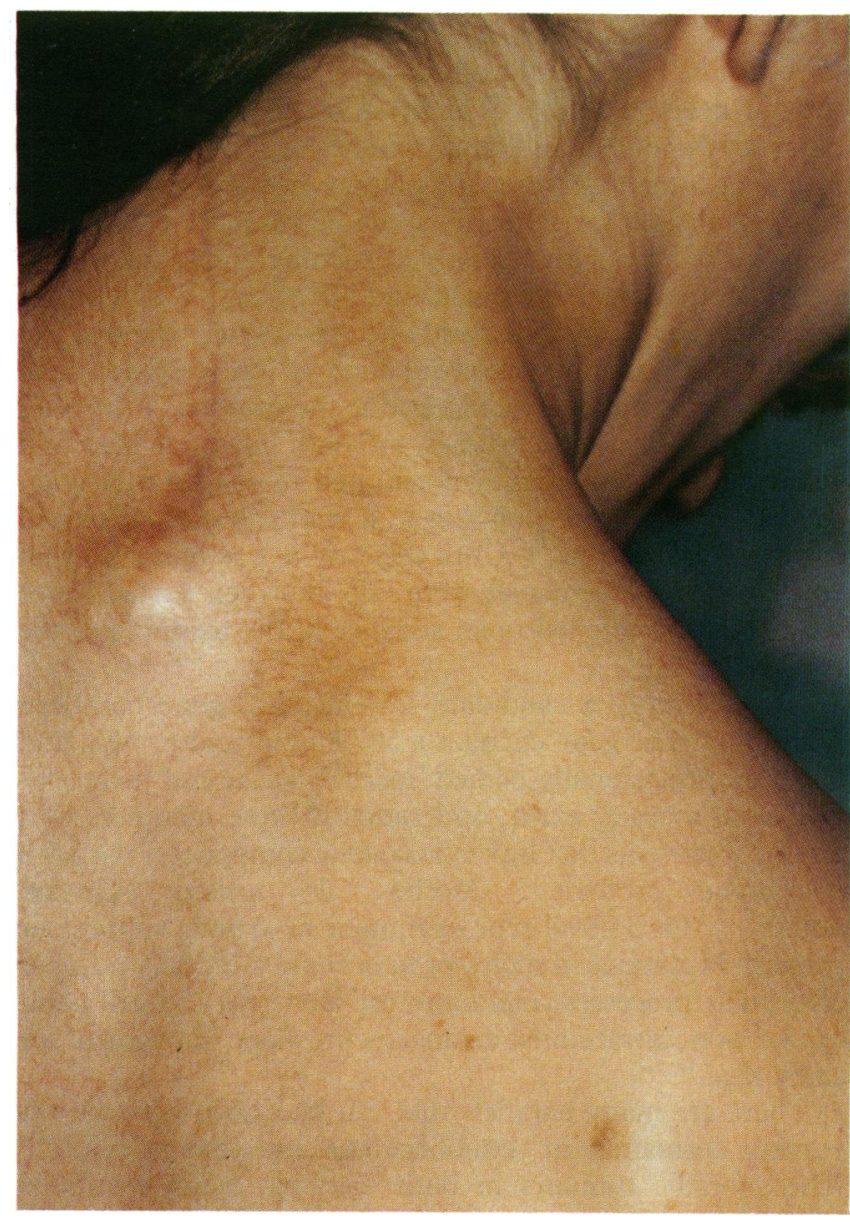

Figure 6 Paraspinal subtle area of hyperpigmentation and subcutaneous schwannoma overlying a spinal tumour in a patient with NF2 (courtesy of VM Riccardi).

pigment epithelial and retinal hamartomas have been described in patients with NF2. Other posterior pole findings include epiretinal membranes, ${ }^{122}$ optic disc gliomas, ${ }^{129} 131$ retinal haemangiomas, medullated nerve fibres, ${ }^{129}$ choroidal naevi ${ }^{40}$ uveal melanoma, choroidal hamartomas. ${ }^{132}$ Other occasionally reported features include Lisch nodules, ${ }^{122} 132133$ hypertrophied corneal nerves, ${ }^{132}$ and conjunctival neurofibroma ${ }^{134}$ It is not yet known whether the NF2 mutation can manifest as ocular abnormalities alone.

Management of patients with NF2

Evaluation of patients with known NF2 should include

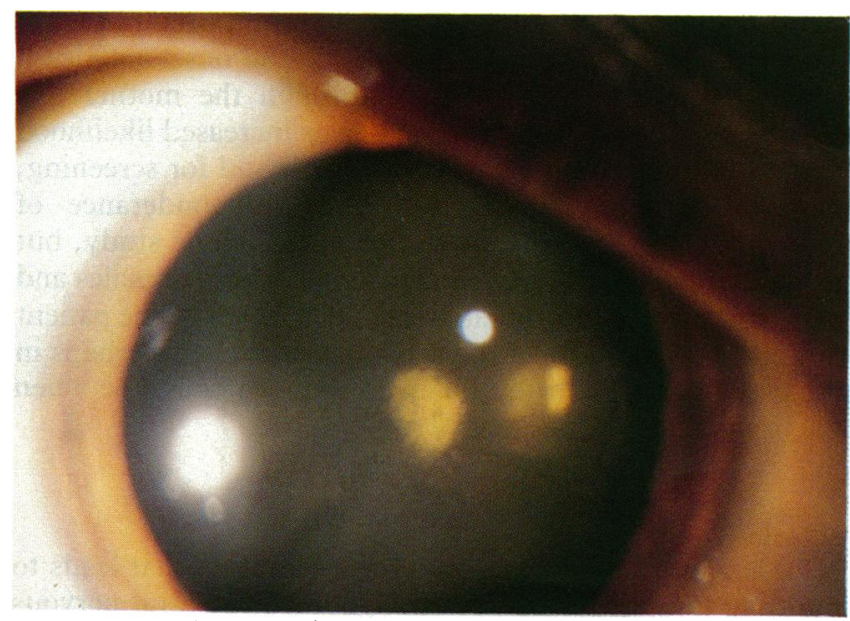

Figure 7 Slit-lamp view of posterior capsular lens opacity in a patient with NF2. regular magnetic resonance imaging with gadolinium for the assessment of vestibular schwannomas, and other central nervous system tumours, and spinal tumours. ${ }^{119}$ In the absence of tumours - for example, vestibular schwannomas, these scans should be performed annually (Fig 9). However, if tumours are present, the scans should be performed more frequently to monitor progression until it is established how rapidly the tumours are growing. Audiometry should be performed annually to assess the progression of vestibular schwannomas unless there is a sudden deterioration of

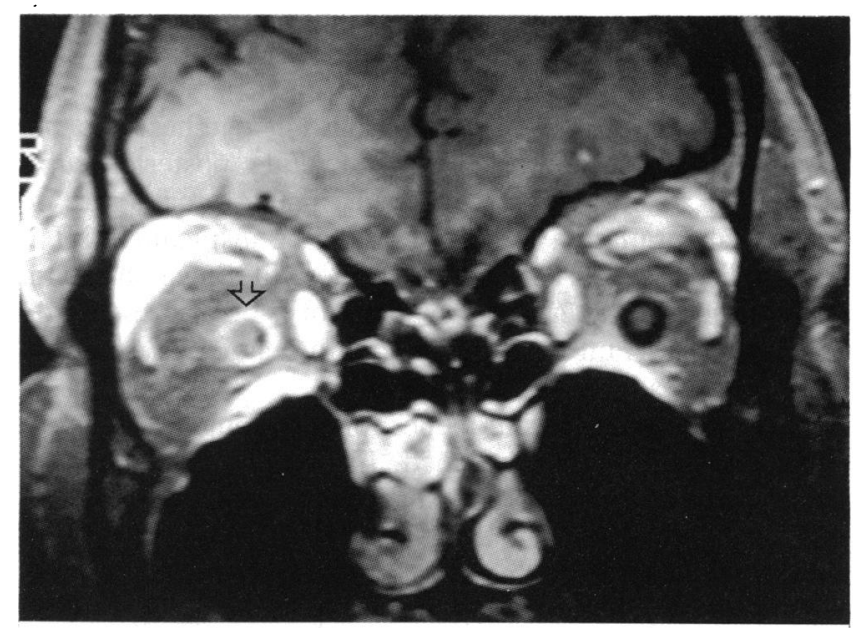

Fig $8 A$

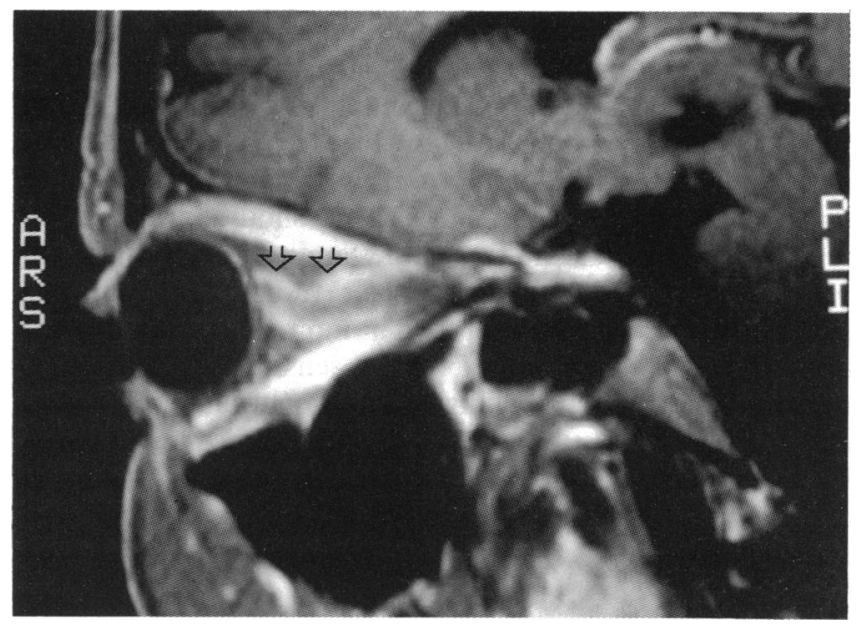

Fig $8 B$

Figure 8 Coronal $(A)$ and axial $(B)$ fat suppression $T 1$ weighted magnetic resonance scan of optic nerve sheath meningioma (arrows) (courtesy of W F Hoyt).

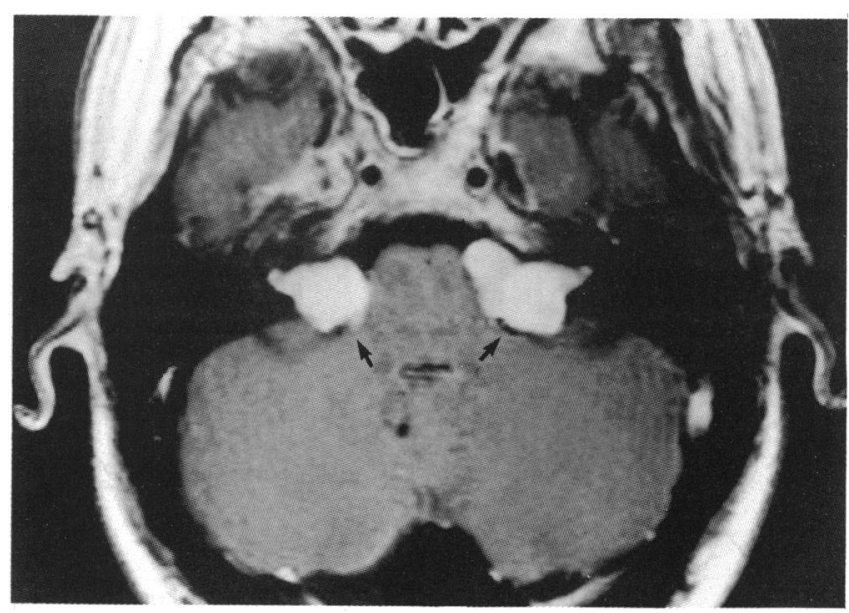

Figure 9 Coronal gadolinium enhanced TI weighted magnetic resonance scan of head demonstrating bilateral vestibular schwannomas (arrows) in a patient with NF2. 
hearing when it should be performed more urgently. Ocular examination is an invaluable asset to confirming the diagnosis of NF2. Family members should be screened and genetic counselling offered. Advice should be given to avoid swimming unaccompanied since several deaths from drowning have been reported. Genetic testing is becoming available.

\section{Screening of at risk individuals}

Individuals at risk for NF2 include first degree relatives of patients with NF2, individuals with a unilateral vestibular schwannoma under the age of 30 , a child with a meningeal or Schwann cell tumour, a person with multiple central nervous system tumours of unknown aetiology, and a person with one or more neurofibromas, scant café au lait patches, and no Lisch nodules. The presence of juvenile posterior subcapsular or cortical cataract or retinal hamartoma is rare in the general population and should raise the suspicion of NF2 in sporadic cases. In familial cases, these findings, although not fulfilling the criteria for diagnosis of NF2 at present are sufficient to warrant full screening with magnetic resonance scanning of head and spine.

Precise management guidelines for screening at risk individuals are still being developed. In familial cases, current chromosome 22 markers are sufficiently close to the NF2 gene to allow linkage analysis which, if informative, will determine those individuals to screen. Before the general availability of genetic testing and in sporadic cases, at risk individuals should be screened at least annually. An ophthalmic and physical assessment is essential. The main purpose of the ophthalmic examination is for initial diagnosis, but complications from cataract, retinal pathology, and orbital tumours may also develop. An initial MR scan of the head and spine with gadolinium enhancement should also be performed searching for vestibular schwannomas or other intracranial or spinal tumours. This should probably be repeated annually, although studies are in progress that will provide more accurate guidelines. Audiometry could be performed as a baseline and then at intervals in the future if tumours develop. Audiometry is less sensitive than magnetic resonance imaging at picking up early schwannomas which may involve the vestibular portion of the eighth nerve alone. If the diagnosis of NF2 is made, the frequency of scans will depend on the size, location, and progression of tumours and symptomatology.

\section{GENETIC ASPECTS}

Physical mapping of the NF2 gene

The NF2 gene is located on chromosome 22q band

\section{Chromosome 22}

$12 \cdot 2$

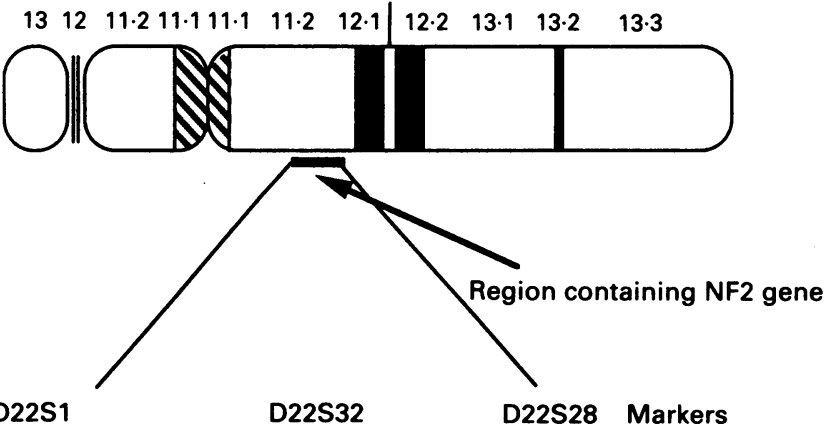

Figure 10 Diagrammatic representation of chromosome 22 depicting region of the NF2, with flanking markers D22S1 and D22S28.
11.2. ${ }^{110} 0^{135-1+0}$ The NF2 gene locus was further narrowed down to a region between the markers D22S1 and D22S28 by tumour deletion studies (Fig 10) in meningiomas and vestibular schwannomas and family studies in a similar fashion to retinoblastoma. ${ }^{141}$ It was assumed that the same genetic locus was responsible for both the sporadic tumours of the type seen in NF2 - for example, meningiomas, vestibular schwannomas, ependymomas, and NF2 itself. If Knudson's two hit hypothesis applied and one copy of the gene was lost in tumour formation, determination of the common area deleted in the tumours would lead to the position of the NF2 gene. Tumour tissue studies on both meningiomas and vestibular schwannomas demonstrated a loss of one chromosome 22 allele, corresponding to loss of the normal second copy (the 'second hit'). Until recently it was observed that entire chromosome copies were lost, but then partial losses were seen and this led to an advance in the mapping of the NF2 gene.

More recently a candidate for the NF2 gene has been found..$^{142-144}$ The gene encodes a 587 amino acid protein and has been provisionally named 'merlin' because of its resemblance to moesin, ezrin, and radixin, three members of a family of proteins that link cytoskeletal components with cell membrane proteins. ${ }^{142}$ Merlin, also called 'schwannomin', ${ }^{143}{ }^{144}$ is a novel type of tumour or growth suppressor protein. Mutations in such a protein could affect any number of cellular processes, including cell division, cell-cell communication, intracellular arrangement, shape, movement, or anchorage. ${ }^{142-14}$

There are many parallels that can be drawn between the tumour formation in retinoblastoma and that in NF2.7980 The sporadic tumours in both diseases, using vestibular schwannomas as the example, develop at a later age and occur unilaterally. In the inherited form, not only does bilateral disease occur earlier, but also other tumour types may develop. It appears that individuals with a mutation at the NF2 locus are predisposed to develop multiple tumour types depending on the tissue that develops a second mutation. This supposes that in a similar way to retinoblastoma one normal copy of the NF2 gene is enough to regulate cell growth. When the second mutation occurs, the cell is able to proliferate in an uncontrolled fashion.

Of special interest in NF2 are the developmental anomalies that can occur in the eye including the retinal hamartomas and cataract. Further characterisation of merlin schwannomin may help to explain why such developmental anomalies occur with single copy germline mutations in the NF2 gene and tumours develop with loss of both copies.

\section{Other genetic influences}

Gene modification by imprinting could be important in NF2. This was suggested by both an earlier age of onset and death when the disease was inherited through the mother. ${ }^{108111}$ However, social circumstances, such as increased likelihood that an affected mother would take her child for screening, may be confounding factors. ${ }^{110} \mathrm{II}$ A preponderance of maternally inherited cases was also noted in one study, but this may be related to reduced paternal fitness in males and non-paternity among sporadic cases."' The sex of the patient did not, however, affect the age at onset, except perhaps in the case of men with the Feiling-Gardner phenotype when the progression may be very slow. ${ }^{113}$

\section{SUMMARY}

NF2 is a rare, dominantly inherited condition that leads to multiple tumour formation throughout the central nervous system and ocular abnormalities. It has been mapped to chromosome 22 . The NF2 gene may be a new type of tumour 
suppressor gene, playing an important role in the interaction between cytoskeletal elements and cell surface proteins. As in $\mathrm{NF} 1$, ocular examination plays an important role in making the diagnosis of NF2.

Division of Ophthalmology,

Childrens Hospital Los Angeles,

University of Southern California, USA

The author gratefully acknowledges Dr V M Riccardi for review of the manuscript and wishes to thank the Vista Foundation for Blind Children, Los Angeles, California for its support.

1 : Mulvihill MJH, Parry DM, Sherman JI, Pikus A, Kaiser-Kupfer MI, Eldridge R. Neurofibromatosis 1 (Recklinghausen disease) and neurofibromatosis 2 (bilateral acoustic neurofibromatosis). An update (NIH Conference). Ann Intern Med 1990; 113: 39-52.

2 Riccardi VM. Neurofibromatosis: phenotype, natural history, and pathogenesis. 2nd ed. Baltimore, MD: Johns Hopkins University Press, 1992.

3 Boltshauser E, Stocker H, Machler M. Neurofibromatosis type 1 in a child of a parent with segmental neurofibromatosis (NF5). Neurofibromatosis 1989; 2: $244-5$.

4 Toonstra J, Dandrieu MR, Ippel PF, Delleman JW, Rupert PHJM Jr, Huitema HB. Are Lisch nodules an ocular marker of the neurofibromatosis gene in otherwise unaffected family members? Dermatologica 1987; 174: 232-5.

5 Aldrovandi U. Monstrorum historia. Cum paralipomenis historiae omnium animalium. Bononiae: Typis Nicolai Tibaldini, 1642

6 Gans O. Ein Fall von Neurofibromatosis (Morbus Recklinghausen) dargestellt von J de Ribera (1588-1656). Hautarzt 1969; 20: 332-3.

7 Zanca A, Zanca A. Antique illustrations of neurofibromatosis. Int $\mathcal{F}$ Dermatol 1980; 19: 55-8.

8 Madigan P, Shaw RV. Neurofibromatosis in thirteenth century Austria. Neurofibromatosis 1988; 1: 339-41.

9 Hecht F. Recognition of neurofibromatosis before von Recklinghausen. Neufofibromatosis 1989; 2: 180-4.

10 Madigan P, Masello M. Report of a neurofibromatosis-like case: Monstrorum Historia, 1642. Neurofibromatosis 1989; 2: 53-6.

11 Tilesius von Tilenau WG. Historia pathologica singularis cutis turpitudinis jo. Godofredi Rheinhardi viri 50 annorum. Leipzig: Siegfried Lebrecht Crusius. Index Cat Surgeon General (1893), 1793: 14.

12 Akenside M. Observations on cancers. Med Trans 1768; 1: 64

13 Ober W. First reported case: multiple neurofibromatosis. Diagnosis 1982: 23-4.

14 Kunze J, Nippert I. Genetics and malformations in art. Berlin: Grosse, 1986

15 Smith RW. A treatise on the pathology, diagnosis and treatment of neuroma. Dublin: Hodges and Smith, 1849

16 Virchow R. Ueber Die Reform der pathologischen und therapeutischen Anschauungen durch die mikroskopischen Untersuchen. Virchows Arch Pathol Anat Physiol Klin Med 1847; 1: 207.

17 Hitchcock A. Some remarks on neuroma, with a brief account of three cases of anomalous cutaneous tumours in one family. Am $\mathcal{F} M e d S c i 1862 ; 43: 320-8$.

18 von Recklinghausen F. Ueber die multiplen Fibrome der Haut und ihre Beziehung zu den multiplen Neuromen. Berlin: Hirschwald, 1882.

19 Crowe FW, Schull WJ, Neel JV. A clinical, pathological, and genetic studv of multiple neurofibromatosis. Springfield, IL: Charles C Thomas, 1956.

20 Riccardi VM. Von Recklinghausen neurofibromatosis. N Engl f Med 1981; 305: 1617-27.

21 Bader JL. Neurofibromatosis and cancer. Ann N Y Acad Sci 1986; 486: 57-65.

22 Sørensen SA, Mulvihill JJ, Nielsen A. Long-term follow-up of von Recklinghausen neurofibromatosis: survival and malignant neoplasms. N Engl f Med 1986; 314: 1010-5.

23 Riccardi V. Type 1 neurofibromatosis and the pediatric patient. Curr Probl Pediatr 1992; 22: 66-106.

24 Martuza R, Philippe I, Fitzpatrick T, Zwaan J, Seki Y, Lederman J. Melanin macroglobules as a cellular marker of neurofibromatosis: a quantitative study. F Inv Dermatol 1985; 85: 347-50.

25 Riccardi VM, Powell PP. Neurofibrosarcoma as a complication of von Recklinghausen neurofibromatosis. Neurofibromatosis 1989; 2: 152-65.

26 Riccardi VM, Lewis RA. Penetrance of von Reckinghausen neurofibromatosis: a distinction between predecessors and descendants. Am $\mathcal{f} \mathrm{Hum}$ Genet 1988; 42: 284-9.

27 Ragge NK, Falk RE, Cohen WE, Murphree AL. Images of Lisch nodules across the spectrum. Eye 1993; 7: 95-101.

28 Huson S, Jones D, Beck L. Ophthalmic manifestations of neurofibromatosis Br f Ophthalmol 1987; 71: 235-8.

29 Burke JP, Leitch RJ, Talbot JF, Parsons MA. Choroidal neurofibromatosis with congenital iris ectropion and buphthalmos: relationship and significwith congenital irs ectropion and buphthalmos: relations

30 Brownstein S, Little J. Ocular neurofibromatosis. Ophthalmology 1983; 90: 1595-9.

31 Collins ET, Batten RD, Neuro-fibroma of the eyeball and its appendages. Trans Ophthalmol Soc UK 1905; 25: 248-57.

32 Spencer WH. Ophthalmic pathology. An atlas and textbook. 3rd ed Philadelphia: Saunders, 1985: 617-9.

33 Gass J. An unusual hamartoma of the pigment epithelium and retina simulating choroidal melanoma and retinoblastoma. Trans Am Ophthalmol Soc 1973; 71: 171-85.

34 Palmer M, Carney M, Combs J. Combined hamartomas of the retinal pigment epithelium and retina. Retina 1990; 10: 33-6.

35 Destro M, D'Amico DJ, Gragoudas ES, Brockhurst RJ, Pinnolis MK, Albert $\mathrm{DM}$, et al. Retinal manifestations of neurofibromatosis. Diagnosis and management. Arch Ophthalmol 1991; 109: 662-6.

36 Wolter JR, Gonzales-Sirit R. Neurofibromatosis of the choroid. Am Ophthalmol 1962; 54: 217-25.

37 Kurosawa A, Kurosawa H. Ovoid bodies in choroidal neurofibromatosis. Arch Ophthalmol 1982; 100: 1939-41.

38 Gartner S. Malignant melanoma of the choroid in von Recklinghausen's disease. Am f Ophthalmol 1940; 23: 73-8.
39 Nordmann J, Brini A. Von Recklinghausen's disease and melanoma of the uvea. Br f Ophthalmol 1970; 54: 641-8.

40 Cotlier E. Café-au-lait spots of the fundus in neurofibromatosis. Arch Ophthalmol 1977; 95: 1990-3.

41 Snell S. Plexiform neuroma (elephantiasis neuromatosis) of temporal region, orbit, eyelid, and eyeball. Notes of three cases. Trans Ophthalmol Soc UK 1903; 23: 157-77.

42 Lewis RA, Gerson LP, Axelson KA, Riccardi VM, Whitford RP. Von Recklinghausen neurofibromatosis. II. Incidence of optic gliomata. Ophthalmology 1984; 91: 929-35.

43 Hoyt WF, Imes RK. Optic gliomas of neurofibromatosis-1 (NF-1): contemporary perspectives. In: Ishibashi Y, Hori Y, eds. Tuberous sclerosis and neurofibromatosis: epidemiology, pathophysiology, biology and management. Amsterdam: Elsevier, 1990: 239-46.

44 Imes RK, Hoyt WF. Magnetic resonance imaging signs of optic nerve gliomas in neurofibromatosis 1 . Am $\mathcal{F}$ Ophthalmol 1991; 111: 729-34.

45 Marshall D. Glioma of the optic nerve as a manifestation of von Recklnghausen's disease. Am F Ophthalmol 1954; 37: 15-36.

46 Hochstrasser H, Boltshauser E, Valavanis A. Brain tumors in children with von Recklinghausen neurofibromatosis. Neurofibromatosis 1988; 1: 233-9.

47 Stern J, Jakobiec FA, Housepian EM. The architecture of optic nerve gliomas with and without neurofibromatosis. Arch Ophthalmol 1980;98:505-11.

48 Seiff SR, Brodsky MC, MacDonald G, Berg BO, Howes ELJ, Hoyt WF. Orbital optic glioma in neurofibromatosis. Magnetic resonance diagnosis of

49 Rush JA, Younge BR, Campbell RJ, MacCarty CS. Optic glioma: long-term follow-up of 85 histopathologically verified cases. Ophthalmology 1982; 89: 1213-9.

50 Packer RJ, Bilaniuk LT, Cohen BH, Braffman BH, Obringer AC, Zimmerman RA, et al. Intracranial visual pathway glioma in children with neurofibromatosis. Neurofibromatosis. 1988; 1:212-22.

51 Imes RK, Hoyt WF. Childhood chiasmal gliomas: update on the fate of patients in the 1969 San Francisco study. BrF Ophthalmol 1986; 70: 179-82.

52 Wong JYC, Uhl V, Wara WM, Sheline GE. Optic gliomas. A reanalysis of the University of California, San Francisco experience. Cancer 1987; 60: 1847-55.

53 Allanson J, Upadhyaya M, Watson G, Partington M, Mackenzie A, Lahey D, et al. Watson syndrome - is it a subtype of type-1 neurofibromatosis? $\mathcal{F}$ Med Genet 1991; 28: 752-6.

54 Pulst SM. Prenatal diagnosis of the neurofibromatoses. Clin Perinatol 1990; 17: 829-44.

55 Fountain JW, Wallace MR, Bruce MA, Seizinger BR, Menon AG, Gusella JF, et al. Physical mapping of a translocation breakpoint in neurofibromatosis. Science 1989; 244: 1085-7.

56 Ledbetter DH, Rich DC, O'Connell P, Leppert M, Carey JC. Precise localization of NF1 to $17 \mathrm{q} 11.2$ by balanced translocation. Am f Hum Genet $1989 ; 44: 20-4$.

57 Menon AG, Ledbetter DH, Rich DC, Seizinger BR, Rouleau GA, Michels VF, et al. Characterization of a translocation within the von Recklinghausen neurofibromatosis region of chromosome 17. Genomics 1989; 5: 245-9.

58 O'Conneli P, Leach R, Cawthon RM, Culver M, Stevens J, Viskochil D, et al. Two NF1 translocations map within a 600-kilobase segment of 17q11.2. Science 1989; 244: 1087-8.

59 Cawthon R, Weiss R, Xu G, Viskochil D, Culver M, Stephens J, et al. A major segment of the neurofibromatosis type 1 gene; cDNA sequence, genomic structure, and point mutations. Cell 1990; 62: 193-201.

60 Viskochil D, Buchberg AM, Xu G, Cawthorn RM, Stevens J, Wolff RK, et al. Deletions and a translocation interrupt a cloned gene at the neurofibromatosis type 1 locus. Cell 1990; 62: 187-92.

61 Wallace MR, Marchuk DA, Andersen LB, Letcher R, Odeh HM, Saulino $\mathrm{AM}$, et al. Type 1 neurofibromatosis gene: identification of a large transcript disrupted in three NF1 patients. Science 1990; 249: 181-6.

62 Marchuk DA, Saulino AM, Tavakkol R, Swaroop M, Wallace MR, Anderson LB, et al. cDNA cloning of the type 1 neurofibromatosis gene: complete $\mathrm{LB}$, et al. cDNA cloning of the type 1 neuronbromatosis gene:

63 DeClue JE, Cohen BD, Lowy DR. Identification and characterization of the neurofibromatosis type 1 protein product. Proc Natl Acad Sci 1991; 88: 9914-8.

64 Gutmann DH, Wood DL, Collins FS. Identification of the neurofibromatosis type 1 gene product. Proc Natl Acad Sci 1991; 88: 9658-62.

65 Seizinger BR. NF1: a prevalent cause of tumorigenesis in human cancers? Nature Genetics 1993; 3: 97-9.

66 Gutmann DH, Collins FS. Recent progress toward understanding the molecular biology of von Recklinghausen neurofibromatosis. Ann Neurol 1992; 31: 555-61.

67 Seidel H, Pompliano D, Knowles J. Exons as microgenes. Science 1992; 257: $1489-90$.

68 Ballester R, Marchuk D, Boguski M, Saulino A, Letcher R, Wigler M, et al. The NF1 locus encodes a protein functionally related to mammalian GAP and yeast IRA proteins. Cell 1990; 63: 851-9.

69 Xu G, O'Connell P, Viskochil D, Cawthon R, Robertson M, Culver M, et al. The neurofibromatosis type 1 gene encodes a protein related to GAP. Cell 1990; 62: 599-608.

70 Martin GA, Viskochil D, Bollag G, McCabe PC, Crosler WJ, Haubruck H, et al. The GAP-related domain of the neurofibromatosis type 1 gene product interacts with ras p21. Cell 1990;63:843-9.

71 Downward J. Rac and Rho in tune. Nature 1992; 359: 273-4.

72 Hall A. ras and GAP - who's controlling whom? Cell 1990; 61: 921-3.

73 Kayes LM, Riccardi VM, Burke W, Dennett RL, Stephens K. Large de novo deletions in a patient with sporadic neurofibromatosis type 1 , mental retardation, and dysmorphism. F Med Genet 1992; 29: 686-90.

74 Upadhyaya M, Chreyson A, Broadhead W, Fryer A, Shaw DJ, Huson S, et al. A $90 \mathrm{~kb}$ deletion associated with neurofibromatosis type 1 . I Med Genet 1990; 27: 738-41.

75 Stark M, Assum G, Krone W. A small deletion and an adjacent base exchange in a potential stem-loop region of the neurofibromatosis 1 gene. Human Genet 1991; 87: 685-7.

76 Wallace MR, Andersen LB, Saulino AM, Gregory PE, Glover TW, Collins FS. A de novo Alu insertion results in neurofibromatosis type 1. Nature 1991; 353: 864-6.

77 Xavier E, Lázaro C, Casals T, Ravella A. Recurrence of a nonsense mutation in the NF1 gene causing classical neurofibromatosis type 1. Hum Genet

8 Jayadel D, Fain P, Upadhyaya M, Ponder MA, Huson SM, Carey J, et al. 
Paternal origin of new mutations in von Recklinghausen neurofibromatosis. Nature 1990; 343: 558-9.

79 Gallie B, Dunn J, Hamel P, Muncaster M, Cohen B, Phillips R. How do retinoblastoma tumours form? Eye 1992; 6: 226-31.

80 Knudson AGJ. Mutation and cancer: statistical study of retinoblastoma. Proc Natl Acad Sci 1971; 68: 820-3.

81 Southern E. Detection of specific sequences among DNA fragments separated by gel electrophoresis. F Mol Biol 1975; 98: 503-7.

82 Musarella MA. Gene mapping of ocular diseases. Surv Ophthalmol 1992; 36: 285-312.

83 Skuse GR, Kosciolek BA, Rowley PR. Molecular genetic analysis of tumors in von Recklinghausen neurofibromatosis: loss of heterozygosity for chromosome 17. Genes, Chromosomes and Cancer 1989; 1: 36-41

84 Menon AG, Anderson KM, Riccardi VM, Chung RY, Whaley JM, Yandell

DW, et al. Chromosome 17p deletions and p53 gene mutations associated with the formation of malignant neurofibrosarcomas in von Recklinghausen neurofibromatosis. Proc Natl Acad Sci USA 1990; 87: 5435-9.

85 Skuse GR, Kosciolek BA, Rowley PT. The neurofibroma in von Recklinghausen neurofibromatosis has a unicellular origin. Am f Hum Genet 1991; 49: $600-7$.

86 El-Azouzi M, Chung RY, Farmer GE, Martuza RL, Black PM, Rouleau GA, et al. Loss of distinct regions on the short arm of chromosome 17 associated with tumorigenesis of human astrocytomas. Proc Natl Acad Sci USA1989; 86: 7186-90.

87 Glover TW, Stein CK, Legius E, Andersen LB, Brereton A, Johnson S. Molecular and cytogenetic analysis of tumors in von Recklinghausen neurofibromatosis. Genes, Chromosomes and Cancer 1991; 3: 62-70.

88 Legius E, Marchuk DA, Collins FS, Glover TW. Somatic deletion of the neurofibromatosis type 1 gene in a neurofibrosarcoma supports a tumour suppressor gene hypothesis. Nature Genetics 1993; 3: 122-6.

89 Menon AG, Gusella JF, Seizinger BR. Progress towards the isolation and characterization of the genes causing neurofibromatosis. Cancer Surv 1990; 9: 689-702.

90 Levine AJ, Momand J, Finlay CA. The p53 tumour suppressor gene. Nature 1991; 351: 453-6.

91 Nigro JM, Baker SJ, Preisinger AC, Jessup JM, Hostetter R, Cleary K, et al. Mutations in the p53 gene occur in diverse human tumour types. Nature 1989; 342: 705-8

92 Srivastava S, Zou Z, Pirollo K, Blattner W, Chang EH. Germ-line transmission of a mutated p53 gene in a cancer-prone family with Li-Fraumeni syndrome. Nature $1990 ; 348$ : 747-9.

93 Vogelstein B. Cancer. A deadly inheritance. Nature 1990; 348: 681-2.

94 Toguchida J, Yamaguchi T, Dayton S, Beauchamp RL, Herrera GE, Ishizaki $\mathrm{K}$, et al. Prevalence and spectrum of germline mutations of the $\mathrm{p} 53$ gene among patients with sarcoma. $N$ Engl f Med 1992; 326: 1301-8.

95 Levine AJ. The p53 tumor-suppressor gene. N Englf Med 1992; 326: 1350-2.

96 Sidransky D, Mikkelsen T, Schwechheimer K, Rosenblum ML, Cavanee W, Vogelstein B. Clonal expansion of p53 mutant cells is associated with brain tumour progression. Nature 1992; 355: 846-7.

97 T'Ang A, Varley JM, Charkraborty S, Murphree AL, Fung Y-KT. Structural rearrangement of the retinoblastoma gene in human breast carcinoma. rearrangement of the ret
Science 1988; 242: $263-6$.

98 Venter DJ, Bevan KL, Ludwig RL, Riley TEW, Jat PS, Thomas DGT, et al. Retinoblastoma gene deletions in human glioblastomas. Oncogene 1991; 6 : 445-8.

99 Li Y, Bollag G, Clark R, Stevens J, Conroy L, Fults D, et al. Somatic mutations in the neurofibromatosis 1 gene in human tumors. Cell 1992;69: 275-81.

100 Andersen LB, Fountain JW, Gutmann DH, Tarlé SA, Glover TW, Dracopoli $\mathrm{NC}$, et al. Mutations in the neurofibromatosis 1 gene in sporadic malignant melanoma cell lines. Nature Genetics 1993; 3: 118-21.

101 Miller M, Hall JG. Possible maternal effect on severity of neurofibromatosis. Lancet 1978; ii: 1071-4.

102 Riccardi VM, Wald JS. Discounting an adverse maternal effect on neurofibromatosis severity. Pediatrics 1987; 79: 386-93.

103 Carnevale A, Santillan Y. Effect of the sex of the progenitor on the clinical manifestations of neurofibromatosis. Revista de Investigacion Clinica 1991 43: 359-63.

104 Shannon KM, Watterson J, Johnson P, O'Connell P, Lange B, Shah N, et al. Monosomy 7 myeloproliferative disease in children with neurofibromatosi type 1: epidemiology and molecular analysis. Blood 1992; 79: 1311-8.

105 Andersen LB, Wallace MR, Marchuk DA, Tavakkol R, Mitchell A, Saulino $\mathrm{AM}$, et al. A highly polymorphic cDNA probe in the NF1 gene. Nucleic Acids Res 1991; 19: 3754 .

106 Hofman KJ, Boehm CD. Familial neurofibromatosis type 1: clinical experience with DNA testing. $\mathcal{F}$ Pediatr 1992; 120: 394-8.

107 Wishart JH. Case of tumours in the skull, dura mater, and brain. Edinburgh Med Surg f 1822; 18: 393-7.

108 Kanter WR, Eldridge R, Fabricant R, Allen JC, Koerber T. Central neurofibromatosis with bilateral acoustic neuroma: genetic, clinical and biochemical distinctions from peripheral neurofibromatosis. Neurology $1980 ; 30$ : 851-9.

109 Eldridge R. Central neurofibromatosis with bilateral acoustic neuroma. Adv Neurol 1981; 29: 57-65.

110 Rouleau GA, Wertelecki W, Haines JA, Hobbs WJ, Trofatter JA, Seizinger $\mathrm{BR}$, et al. Genetic linkage of bilateral acoustic neurofibromatosis to a DNA marker on chromosome 22. Nature 1987; 329: 246-8.

111 Evans DGR, Huson SM, Donnai D, Neary W, Blair V, Teare D, et al. A genetic study of type 2 neurofibromatosis in the United Kingdom: I prevalence, mutation rate, fitness and confirmation of maternal transmission effect on severity. F Med Genet 1992; 29: 841-6.
112 Mayfrank L, Wullich B, Wolff G, Finke J, Gouzoulis E, Gilsbach JM. Neurofibromatosis 2: a clinically and genetically heterogeneous disease? Report on 10 sporadic cases. Clin Genetics 1990; 38: 362-70.

113 Eldridge R, Parry D. Neurofibromatosis 2: evidence for clinical heterogeneity based on 54 affected individuals studied by MRI with gadolinium, 19871991. First International Conference on acoustic neuroma, Copenhagen: Kugler, 1991

114 Parry DM, Eldridge R. Acoustic neuromas: clinical characteristics of heritable bilateral tumors. Consensus development conference, National Institutes of Health, 1991: 31-6.

115 Feiling A, Ward E. A familial form of acoustic tumor. BMF 1920; 1: 496-7.

116 Gardner WJ, Frazier CH. Bilateral acoustic neurotibromas. A clınical study and field survey of a family of five generations with bilateral deafness in thirty-eight members. Arch Neurol Psychiatr 1930; 23: 266-302.

117 Lee DK, Abbott ML. Familial central nervous system neoplasia. Arch Neurol 1969; 20: 154-60.

118 Young DF, Eldridge RE, Nager GT, Deland FH, McNew J. Hereditary bilateral acoustic neuroma (central neurofibromatosis). Birth Defects 1971; 7: 73-86.

119 Martuza RL, Eldridge R. Neurofibromatosis 2 (bilateral acoustic neurofibromatosis). N Engl f Med 1988; 318: 684-8.

120 Pearson-Webb M, Kaiser-Kupfer M, Eldridge R. Eye findings in bilateral acoustic (central) neurofibromatosis. Association with presenile lens opacities and cataracts but absence of Lisch nodules. $N$ Englf Med 1986; 315: 1553-4.

121 Kaiser-Kupfer M, Freidlin V, Datiles M, Edwards P, Sherman J, Parry D, et $a l$. The association of posterior capsular lens opacities with bilateral acoustic neuromas in patients with neurofibromatosis type 2. Arch Ophthalmol 1989; 107: $541-5$.

122 Kaye L, Rothner A, Beauchamp G, Meyers S, Estes M. Ocular findings associated with neurofibromatosis type 2. Ophthalmology 1992; 99: 1424-9.

123 Shapland CD, Greenfield JG. A case of neurofibromatosis with meningeal tumour involving the left optic nerve. Trans Ophthalmol Soc UK 1935; 55: 257-79.

124 Cunliffe IA, Moffat DA, Hardy DG, Moore AT. Bilateral optic nerve sheath meningiomas in a patient with neurofibromatosis type $2 . \mathrm{Br} \mathcal{F}$ Ophthalmol 1992; 76: 310-2.

125 Landau K, Dossetor FM, Hoyt WF, Muci-Mendoza R. Retinal hamartoma in neurofibromatosis type 2. Arch Ophthalmol 1990; 108: 328-9.

126 Good W, Brodsky M, Edwards M, Hoyt W. Bilateral retinal hamartomas in neurofibromatosis type 2. Brf Ophthalmol 1991; 75: 190.

127 Sivalingam A, Augsburger J, Perlongo G, Zimmerman R, Barabas G. Combined hamartoma of the retina and retinal pigment epithelium in a patient with neurofibromatosis type 2. F Pediatr Ophthalmol Strabismus 1991; 28: 320-2.

128 Bouzas EA, Parry DM, Eldridge R, Kaiser-Kupfer MI. Familial occurrence of combined pigment epithelial and retinal hamartomas associated with neurofibromatosis 2. Retina 1992;12: 103-7.

129 Goldsmith J. Neurofibromatosis associated with tumors of the optic papilla. Arch Ophthalmol 1949; 41: 718 .

130 Saran N, Winter FC. Bilateral gliomas of the optic discs associated with neurofibromatosis. Am F Ophthalmol 1967; 64: 89.

131 Dossetor FM, Landau K, Hoyt WF. Optic disk glioma in neurofibromatosis type 2. Am F Ophthalmol 1989; 108: 602-3.

132 Garretto NS, Ameriso S, Molina HA, Arberas C, Salvat J, Monteverde D, et al. Type 2 neurofibromatosis with lisch nodules. Neurofibromatosis 1989; 2:315-21

133 Charles SJ, Moore AT, Yates JRW, Ferguson-Smith MA. Lisch nodules in neurofibromatosis type 2. Arch Ophthalmol 1989; 107: 1571-2.

134 Perry H. Isolated neurofibromas of the conjunctiva. Am F Ophthalmol 1992; 89: 112-3.

135 Seizinger BR, Martuza RL, Gusella JF. Loss of genes on chromosome 22 in tumorigenesis of human acoustic neuroma. Nature $1986 ; 322: 644-7$.

136 Seizinger BR, de la Monte S, Atkins L, Gusella JF, Martuza RL. Molecular genetic approach to human meningioma: loss of genes on chromosome 22 Proc Natl Acad Sci 1987; 84: 5419-23.

137 Seizinger BR, Rouleau G, Ozelius LJ, Lane AH, George-Hyslop PS, Huson S, et al. Common pathogenetic mechanism for three tumor types in bilateral acoustic neurofibromatosis. Science 1987; 236: 317-9.

138 Wertelecki W, Rouleau GA, Superneau DW, Forehand LW, Williams JP, Haines JL, et al. Neurofibromatosis 2: clinical and DNA linkage studies of a large kindred. $N$ Engl F Med 1988; 319: 278-83.

139 Narod S, Parry D, Parboosingh J, Lenoir G, Ruttledge M, Fischer G, et al. Neurofibromatosis type 2 appears to be a genetically homogeneous disease. Am ₹ Hum Genet 1992; 51: 486-96.

140 Wolff R, Frazer K, Jackler R, Lanser M, Pitts L, Cox D. Analysis of chromosome 22 deletions in neurofibromatosis type 2-related tumors. Am $\mathcal{F}$ Hum Genet 1992; 51: 478-85.

141 Cavenee WK, Dryja TP, Phillips RA, Benedict WF, Godbout R, Murphree $\mathrm{AL}$, et al. Expression of recessive alleles by chromosomal mechanisms in retinoblastoma. Nature 1983; 305: 779-84.

142 Trofatter JA, MacCollin MM, Rutter JL, Murrell JR, Duyao MP, Parry DM, et al. A novel moesin-, ezrin-, radixin-like gene is a candidate for the neurofibromatosis 2 tumor suppressor. Cell 1993; 72: 791-800

143 Kinzler KW, Vogelstein B. A gene for neurofibromatosis 2. Nature 1993; 363 . 495-6.

144 Rouleau GA, Merel P, Lutchman M, Sanson M, Zucman J, Marineau C, et al. Alteration in a new gene encoding a putative membrane-organizing protein
causes neurofibromatosis type 2 . Nature $1993 ; 363: 515-21$. 